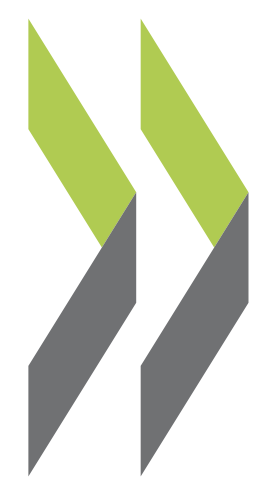

PEB Exchange, Programme on Educational Building 2003/18

\title{
An Environmentally \\ Sustainable Development in Australia
}

\section{Ruth Woods}

https://dx.doi.org/10.1787/643454680621 


\section{AN ENVIRONMENTALLY SUSTAINABLE DEVELOPMENT IN AUSTRALIA}

The future Kelvin Grove Urban Village in Queensland, Australia, is an example of how principles of environmentally sustainable design have translated into practice. Those responsible for the new project recognise the importance of building design that respects the environment by using resources efficiently and minimising pollution. The site's master plan requires developers to comply with environmentally sustainable design principles adopted for the site's buildings.

The 17-hectare mixed-use development of Kelvin Grove Urban Village will comprise university facilities, residential and commercial buildings, and public facilities. Queensland University of Technology (QUT) and the Queensland Department of Housing agreed to develop jointly a master plan for the site, located within two kilometres of Brisbane City. QUT, whose Kelvin Grove Campus backs onto the site, was keen to expand and particularly to develop a presence on the busy arterial Kelvin Grove Road. The state housing authority saw it as a means to develop land that could be sold to support their low income housing schemes both within and external to the site. There are more than 800 residential dwellings planned, with around 100 of these expected to be developed by a new state and local government-supported affordable housing company.

The very concept of this partnership on a brownfield site, its master planning and its development set out to pursue a broad sustainability agenda. Private and public developers, on acquiring a site, are required to provide a statement of compliance with the environmentally sustainable design policy set out in the implementation plan for all future development and to apply minimum performance criteria. Performance criteria for environmentally sustainable design were developed with the intention to translate broad community sustainability principles into specific practices to be adopted in the design and construction of the individual buildings. The minimum performance criteria will be continually revised to reflect changing practices and further contribute to the community sustainability goals.

Development bonuses may be provided in some circumstances in order to achieve environmentally favourable

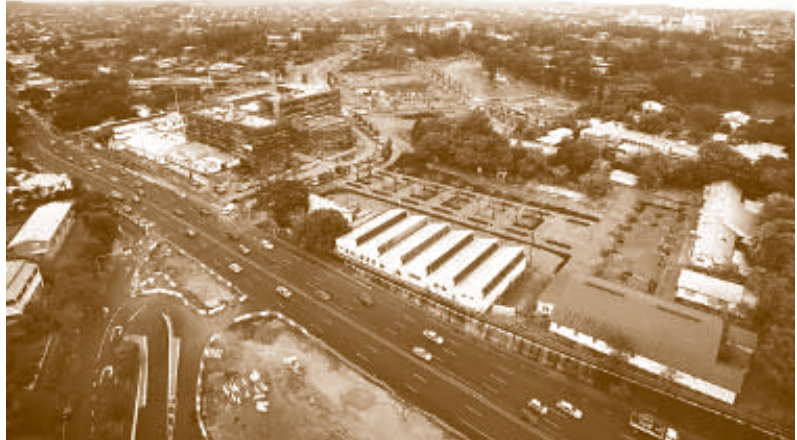

Advanced construction of the Creative Industries Precinct for QUT in the left, middle distance and progress on the new road network. Creative Industries Precinct

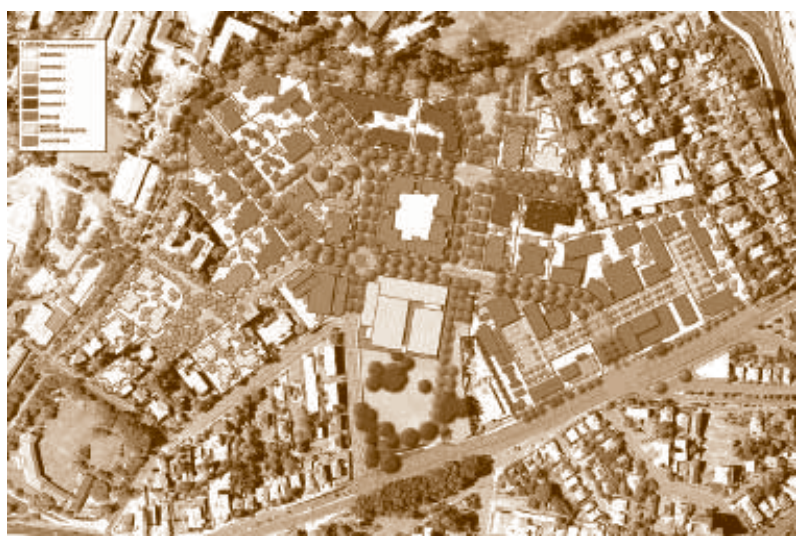

outcomes which would otherwise be difficult to justify economically. Subject to the local authority's approval, a bonus of up to $10 \%$ in additional gross floor area may be accorded to developments that include sustainability measures, such as for facilitating on-site wastewater treatment or generating electricity through solar photovoltaic cells.

The table below provides a sampling of requirements from six of the nine priority areas for the project's environmentally sustainable design strategy and minimum performance criteria; the remaining areas are transportation, biodiversity and atmospheric management.

For more information, contact:

Ruth Woods

Associate Director, Major Projects

Facilities Management

Queensland University of Technology

Brisbane, Australia

Tel.: 613864 3003, fax: 6138643625

E-mail: ra.woods@qut.edu.au 
1. Energy efficiency

\section{Hot water systems}

Ensure that hot water systems not only meet demand but also reduce reliance on supply infrastructure and minimise greenhouse gas generation.

\section{Lighting}

Design buildings to maximise use of natural light and minimise energy use for lighting.

\section{Space heating and cooling}

Design buildings to reduce the need for heating or cooling and ensure that any mechanical heating or cooling will be energy efficient.

\section{Water management}

\section{Water conservation}

Reduce the demand on potable water supplies and infrastructure by reducing the peak demand and annual usage within the development.

\section{Stormwater management}

Reduce the demand on town stormwater systems during peak stormwater flows and on the town water supply by collecting and reusing stormwater on site.

\section{Indoor air quality management}

\section{Low off-gassing paints and adhesives}

Use paints with low pollution emittance on building interiors.

\section{Indoor pest control}

Use mechanical means rather than chemicals to exclude pests from buildings.

\section{Waste management}

Construction materials

Take into consideration the environmental effects of construction materials and products over their whole life cycle.

\section{Construction waste}

Reduce the amount of construction waste and conserve resources through reuse or recycling to reduce the environmental impact from material manufacturing and transport.

\section{Light and noise pollution}

\section{Light spill}

Reduce light pollution from the development onto adjacent residential properties and the local environment.

\section{Noise pollution}

Reduce the impact of noise generated within the development.

\section{Monitoring and implementation}

\section{User information}

Inform tenants of the sustainability measures included within their unit and what they can do to help minimise energy consumption and waste.
Install all buildings with energy efficient gas or solar hot water storage systems.

Design buildings so that lighting consumes no more than 12 watts $/ \mathrm{m}^{2}$ averaged over the whole building through the use of good design and energy efficient lighting.

Ensure that heating and cooling systems target only critical spaces and be zoned for maximum efficiency.

Install AAA-rated flow restricted showerheads and taps in all developments. Use timers and soil moisture sensors on all irrigation systems. Use infrared Sensor Activated urinals. Ensure that $50 \%$ of plants introduced to landscaped areas are native to Southeast Queensland.

Use porous pavements where pavement is unavoidable, and where possible direct the run off to gardens, storage or retention basins.

Use zero-VOC (volatile organic compounds) paints on internal walls (i.e. no VOC's added in the manufacturing process). Use only products and adhesive compounds with no or low VOC's. Use floor finishes with no or low VOC's.

Ensure that the buildings are sealed and caulked and that points of entry are protected by adequate mechanical means from insect and pest entry. Provide properly fitting door seals on all exterior and hallway doors. Cover all ventilation openings, including openable windows, with insect screens.

Select construction materials and products based on balancing the following environmental criteria: recyclability; sustainable sourcing; low embodied energy (the energy used in their manufacture); low pollution from manufacturing; low transport costs; minimal environmental impact; durability and minimal maintenance; nonhazardousness; and eco-labelling and certification.

Implement an on-site recycling system for waste materials including separating waste (timber for reuse, concrete and bricks for crushing and steel and copper for recycling). Reuse or recycle demolition materials. Recycle cardboard, metals, concrete, brick, asphalt, beverage containers, clean dimensional wood, plastic, glass, gypsum board and carpet.

Control light spill so that a minimum is directed beyond the site boundaries or upwards.

Ensure that sources of noise, such as car parks, are not directed towards the neighbouring properties. Attenuate noise of the source, and locate noisy activities far from residential areas in particular.

Provide future owners and tenants with a user pack or brochure which includes information on use and maintenance of the sustainability measures. This should also explain functions and benefits. 